\title{
'And it shall come to pass on that day, the Lord will whistle for the fly which is at the end of the water channels of Egypt, and for the bee which is in the land of Assyria' (Is 7:18): Traumatic impact of the Covid-19 virus as a lens to read Isaiah 7:18-25
}

\begin{tabular}{|c|c|}
\hline \multicolumn{2}{|c|}{$\begin{array}{l}\text { Authors: } \\
\text { Elizabeth Esterhuizen }{ }^{1} \text { (D) } \\
\text { Alphonso Groenewald }^{1} \text { (D) }\end{array}$} \\
\hline \multicolumn{2}{|c|}{$\begin{array}{l}\text { Affiliations: } \\
{ }^{1} \text { Department of Old } \\
\text { Testament and Hebrew } \\
\text { Scriptures, Faculty of } \\
\text { Theology and Religion, } \\
\text { University of Pretoria, } \\
\text { Pretoria, South Africa }\end{array}$} \\
\hline \multicolumn{2}{|c|}{$\begin{array}{l}\text { Research Project Registration: } \\
\text { Project Leader: A. Groenewald } \\
\text { Project Number: } 02428024\end{array}$} \\
\hline \multicolumn{2}{|c|}{$\begin{array}{l}\text { Description: } \\
\text { This research is part of the } \\
\text { project 'Prophetic literature } \\
\text { through the lens of Trauma } \\
\text { and Disaster studies', } \\
\text { directed by Prof. Dr Alphonso } \\
\text { Groenewald, Department of } \\
\text { Old Testament Studies, } \\
\text { Faculty of Theology, } \\
\text { University of Pretoria. }\end{array}$} \\
\hline \multicolumn{2}{|c|}{$\begin{array}{l}\text { Corresponding author: } \\
\text { Alphonso Groenewald, } \\
\text { alphonso.groenewald@up. } \\
\text { ac.za }\end{array}$} \\
\hline \multicolumn{2}{|c|}{$\begin{array}{l}\text { Dates: } \\
\text { Received: } 11 \text { Sept. } 2020 \\
\text { Accepted: } 05 \text { Feb. } 2021 \\
\text { Published: } 18 \text { Mar. } 2021\end{array}$} \\
\hline \multicolumn{2}{|l|}{ Read online: } \\
\hline 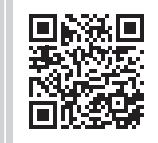 & $\begin{array}{l}\text { Scan this QR } \\
\text { code with your } \\
\text { smart phone or } \\
\text { mobile device } \\
\text { to read online. }\end{array}$ \\
\hline
\end{tabular}

In this article the impact of the Covid-19 virus will be used as a lens to read this Isaianic text. The collective threat of the corona-virus causes trauma on societies and communities on different levels: psychological, physical, existential and communal trauma.

Isaiah 7:18-25 also tells us of an historic event which caused extreme trauma to its audience. Verse 18 describes the arrival of the Assyrian army. The prophet compares the Assyrian hosts to the flies "in the rivers of Egypt", and to the bees in Assyria; that is to say, the invaders will be the innumerable and speedy warriors of the Assyrian king. This portrayal is expanded stating that the flies and the bees will swarm all over the land, penetrate every corner and crack and it will be impossible to get rid of them. The plague of "flies" in the metaphor represents the large numbers, while the "bees" are clearly the aggressive and terrifying ones in this metaphor. Just as the Assyrians, who are about to appear as an unwanted and troublesome multitude of flies and bees from which Ahaz will be unable to free himself and his kingdom, the Covid-19 virus is causing havoc and wreckage to societies all over the world.

Contribution: This article reflects theologically on the immense psychological and existential damage of trauma caused by the terrifying and laming fear this virus has on the mental wellbeing of a society. The theological reflections will engage with a biblical text which also reflects on the traumatic effects of threat and fear that lamed a society.

Keywords: Trauma Studies; Isaiah; psychology; pandemic; Covid-19; metaphor; posttraumatic stress.

\section{Introduction}

Seldom has the threat of disease occupied so much of our thinking. Everyday, we are confronted with news about the coronavirus disease 2019 (Covid-19) pandemic and the threatful consequences it holds in disrupting the equilibrium of our lives. This constant salvo can result in increased anxiety which has an immediate effect on our physical and mental well-being. The relentless feeling of threat and anxiety may have insidious effects on psychological, existential and communal trauma. This can be attributed to the fact that some evolved responses to disease embedded in survival, fear of contagion and evasion can make us more collective and conformist in the face of looming trauma.

Just like trauma, pandemics and plagues have been part of life since the beginning of time. It is part of everyday life, as it has been in the past and as it will be in the future. How we deal with these traumatic threats depends largely on what we can learn from history and the paradigm shift we can make for future understanding and growth.

How to cite this article: Esterhuizen, E. \& Groenewald A., 2021, "And it shall come to pass on that day, the Lord will whistle for the fly which is at the end of the water channels of Egypt, and for the bee which is in the land of Assyria" (Is 7:18): Traumatic impact of the Covid-19 virus as a lens to read Isaiah 7:18-25', HTS Teologiese Studies/Theological Studies 77(3), a6333. https://doi.org/10.4102/hts. v77i3.6333

Copyright: (C 2021. The Authors. Licensee: AOSIS. This work is licensed under the Creative Commons Attribution License.

Note: Special Collection: Being a Change Agent in a (Post-) Covid South Africa, sub-edited by Erna Oliver (UNISA). 


\section{Understanding trauma, pandemic and plague}

Luckhurst $^{1}$ aptly equates the phenomenon of trauma as 'an exemplary conceptual knot' that entangles the fear of the unknown as a trauma response. For Luckhurst (2008:14), the knot resembles an amalgam of trauma characteristics fused into sub-categories of traumatic experiences. These experiences cross between subject and object, human and non-human, and society and nature. Being in the storm of the Covid-19 pandemic, the lines become blurred between the virus symptoms and the trauma that is caused by Covid-19. Traumatic suffering in the face of a pandemic exemplifies individual trauma experiences whereupon collective trauma responses are forthcoming.

Despite our best wishes, this pandemic and trauma have become part of our everyday life, the same as trauma had been part of the Judean people's lives. Trauma, whether individual or collective, is structured by complex emotional feelings, thoughts of fear and behaviour that becomes a new distorted 'normal'. The constant bombardment of news on all social media platforms, we are more than ever aware of the destructive path of the Covid-19 pandemic around the globe and also within our own community and nucleus environment. Round-the-clock news coverage of images of tragedy, suffering and loss can overwhelm the nervous system and create trauma. Pandemics and trauma inflict great instability and it breaks patterns of normality. Outside our homes, safety now is never assured and the safe places of refuse become a threat. When disaster strikes, assumptions of safety are shattered, and it becomes increasingly more difficult to regain any sense of normality. A trauma lens enhances our perspective of understanding how pandemic suffering affects psychological and spiritual wellbeing and how we might grow from it. Huremović (2019) wrote that:

$[V]$ ery few phenomena throughout human history have shaped our societies and cultures the way outbreaks of infectious diseases have; yet remarkably little attention has been given to these phenomena in behavioural science and social studies. (p. 7)

Until the outbreak of the Covid-19 pandemic, very little has been written about the trauma of pandemics from a biblical perspective as well.

The text of Isaiah 7:18-25 portrays not only the historical events of plagues of pandemical propositions but also denotes the trauma experiences that await the people of Judah. The word trauma derives from the Greek word that means wound. Altmaier (2019:2) ${ }^{2}$ explained that the word in its origin implied physical injuries in and on the body, which could lead to disability or death. Today we know that trauma is much more than a mere physical wound but that it also

1.Luckhurst (2008:14) explained the concept of trauma in an intellectual landscape that is post-Freudian in understanding and perspective regarding trauma.

2.Altmaier, in her book Promoting positive processes after trauma (2019:3-10), elaborates on different types of trauma with references to mass violence, sexual assault, intimate partner violence and accidents. embodies psychological, emotional, existential and collective events that overwhelm, distress, and cause anxiety and fear. O'Donnell and Cross (2020:12) rightfully stated that it is not easy to define trauma because of the different perspectives and interpretations of what trauma is. The conundrum lies in the overwhelming nature of trauma and the impact it has on the individual and the collective. Trauma latches on, branches out and encircles moments of threat, disasters and pandemics in forever mutating ways just as Covid-19 changes the symptoms of infection.

In Isaiah 7:18, a vivid description is given of the arrival of the Assyrian and Egyptian armies. The metaphorical comparison is made to flies and bees that would invade the land. These swarms of insects can be seen and understood as a plague that was going to invade the land of Judah. The word plague derives from the Greek word plaga that means strike or blow. Huremović (2019:8) wrote that the word plague, 'describes a particular, virulent contagious febrile disease causing a high rate of mortality'. Throughout the biblical context, this unremitting looming fear of danger shaped the historical landscape. These traumatic historical events, as described in Isaiah 7:18-25, are called traumatic stressors. Examples of these stressors include constant threat of war, terror, pandemic and illness, loss of loved ones, physical danger and constant fear. Herman (1992:33) ${ }^{3}$ defined these stressors as 'traumatic events' that 'overwhelm the ordinary systems of care that give people a sense of control, connection and meaning'. As we read the events in Isaiah 7:18-25, we know the outcome of the traumatic danger as it is delineated in the following chapters of the book Isaiah. At the time of this writing, the complete effects and trauma of the Covid-19 pandemic were far from clear. Erikson (1995a:194) underlined this uncertainty when he stated that traumatized people often feel that they have lost an important measure of control over the circumstances of their own lives and are thus vulnerable'. The biblical text of Isaiah 7:18-25 gives us an insight into the looming trauma and a lens to understand it, especially in the uncertain times of the Covid-19 pandemic. In this regard, the well-known infectious disease and public health reporter Helen Branswell ${ }^{4}$ noted, 'Having written about the possibility of something like this for years, I still find myself really startled that it's happening'. This sense of shock and fear over Covid-19 is a collective and communal experience worldwide. Erikson (1995b:153-155) made a distinction between individual and collective trauma by stating that collective trauma inherently impacts the fibre of society and affects the fundamental unit of being a community. In the case of Covid-19 and the text of Isaiah 7:18, unexpected suffering and trauma awaited the nations. In the face of a pandemic, the individual suffers and the community suffer as the two are very much interrelated. The case in point is the unpredictability of the trauma and the continuous uncertainty when the trauma might occur.

3. Herman further eludes in her book Trauma and recovery: The aftermath of violence - From domestic abuse of political terror (1992:33) that these traumatic events can involve physical and psychological threats and feelings of helplessness.

4.Branswell was part of a panel discussion on 07 March 2020 as reported by Joseph (2020). 
Both the audience of Isaiah 7 and the audience of the Covid-19 infected world endure the catastrophe of infestation.

Collective traumatic events according to Saul (2014:37) opens up existing fault lines in communities. These inconsistencies include discrimination, social and economic disparities, other previous historical traumas and even racism. Traumatising events are often driven by fear, anger, anxiety and the opportunity for gain. In Isaiah 7 , these fault lines are seen in power imagery of bees and flies where the Assyrians and possibly Egypt too will invade Judah to make them a vassal state of Assyria. The metaphors of bees and flies according to Aster (2017:101) imply to draw blood and sting and they therefore express these two invading kingdoms' practice of 'resource extraction' and gain. Covid-19 also widely opened these fault lines within communities and nations barring our vulnerabilities. These fault lines, when viewed from a trauma perspective, not only result in ongoing trauma and possible post-traumatic stress, but also provide the opportunity for growth and hope. Even though our very existence is threatened, hope still remains the central core of human existence. Hope is paradoxical and Altmaier (2019:31) wrote that if hope is evident, so must be despair. Esterhuizen (2016:47) wrote that even after trauma, individuals and communities can create hope and positive outcomes. She further stated (2016:48) that on the equilibrium of traumatic outcome, trauma penetrates, hurts and leaves scars but hope after trauma instils resilience, strength and growth (cf. also Groenewald 2018).

\section{Literary context of Isaiah $7^{5}$}

This chapter belongs to the first major section of the book of Isaiah (Chapters 1-12). Structurally, it is part of the core of the book, which became known - at least since Karl Budde as the Isaiah Memoir (Denkschrift - 6:1-9:6 [Eng. V. 7]) (Blenkinsopp 2000:223; Tull 2010:157). For most of the 20th century, this 'core' was regarded as an independent and separate text, which was written by the 'prophet' himself. According to this theory, it was only later inserted between the woe and judgement oracles, which begin in Chapter 5 and again resume in Chapter 9. Today most commentators argue that - even when - the core of this narrative may date back to Isaiah's time, these chapters were thoroughly reworked and edited in order to contrast the narratives of Isaiah 36-37 (Tull 2010:157; cf. also Williamson 2018:103). ${ }^{6}$ These chapters (36-37) thus function as a counter narrative to the narrative we have in Isaiah 6-8.

Although we have most of our knowledge of the prophetic figure from Chapters 7 and 8 , the main focus in these chapters

5.Cf. also Esterhuizen (2016:70ff) with regard to this section for an extensive analysis and overview.

6.Cf. also Reventlow (2008:37-38) who infers as follows: '... the opinion of an Isaianic authorship of the whole complex seems to me to be untenable. And I am not alone in my unease with the established position ... As regards the other passages in the "Denkschrift" complex, one can even say that the first-person style is no secure indication that we have the personal testimony of the prophet. For example, the first-person speeches of Job, which are universally accepted as fiction, provide clear evidence that the use of the stylistic device cannot be used to secure the authorship of a given passage'. is actually not on the prophet himself, but more on King Ahaz (Everson 2019:32). In the beginning of Chapter 7, we become spectators of the small world of the kingdom of Judah and its capitol city, Jerusalem. Judah (and king Ahaz) were threatened by the kings of Israel (Pekah) and Syria (Rezin). An imminent attack of a combined military force was looming as these two kings were preparing to invade Judah and planning to get rid of Ahaz as king of Judah. This military invasion was remembered as the Syro-Ephraimite coalition. According to 2 Kings 16, Ahaz requested assistance from the Assyrian king Tiglath-Pileser, but this intervention came at a very high price and Ahaz had to pay tribute to the Assyrian king. As a result of Ahaz's decision, a period of more Assyrian occupation and domination within Judah started. When Isaiah spoke to Ahaz, he probably begged to him not to request help from the Assyrian Empire (Everson 2019:32-34).

\section{According to Brueggemann (1998), Chapter 7:}

[i]s one of the most complex and elusive in the entire book of Isaiah ... The entire chapter makes clear the prophetic faith is inescapably situated midst the vagaries of the historical-political process, and it is in such a context that the concrete risks of faith must be run. (pp. 63-64)

Childs (2001:63) correctly observed that everybody who has ever analysed this chapter can attest to the extreme challenges it poses to the exegete. It is widely accepted that this chapter is a multilayered text, which is the result of a long process of growth and Fortschreibung. The challenge the exegete faces is therefore to understand the full richness of the different layers (voices) in this text in relation to the text's final literary form. ${ }^{7}$

Chapter 7 is written in prose and continues the narrative sequence, which began in the previous chapter (6:1). Narrative is uncharacteristic for the book of Isaiah; we otherwise only have narratives in Chapters 20 and 36-39, which are written as third-person sketches. Chapter 7 uses the third-person narration, unlike Chapters 6 and 8 in which the 'prophet' speaks in the first person, and is thus part of an autobiographical-biographical-autobiographical sequence. In Chapter 7, the encounter between Isaiah and King Ahaz is narrated in the third person (cf. also Blenkinsopp 2000:223; Tull 2010:157; Williamson 2018:103). According to Kim (2016:58), this shift in the prophetic speech - from the firstperson to the third and back again to the first - may indicate that Isaiah 7 only fits loosely within the larger corpus. However, for him, 'Isaiah 7 stands out and can be seen as a focal centre of Isaiah 5-10' (Kim 2016:58).

In Chapter 7, we have a further development of themes, phrases and metaphors, which begin in Chapter 6 (Prokhorov 2015:112). Although Chapter 7 confirms Chapter 6's message of destruction, it clearly delineates despair and hope from one another (cf. also Esterhuizen 2016:71). Childs (2001:62)

7.Given the aim of this article, we have chosen to focus primarily on the synchronic aspects of these texts; diachronic aspects may be referred to where appropriate. In aspects of these texts; diachronic aspects may be referred to where appropriate. In
other words, our aim is not to reconstruct an 'original' text within the final form of the text. 
also confirmed this observation when he stated that Chapter 6 looks forward and Chapter 7 'offers the first illustration of the hardening process at work in King Ahaz's rejection of the challenge of faith'.8

This chapter, with all its complexities, can only be understood against the background of the current socio-political context. This requires the reader to involve all the role players, the political crisis, its subsequent social dynamics and implications, which are all set against the political developments during the reign of Ahaz, the grandson of Uzziah. According to Esterhuizen (2016:71), Isaiah's role as a prophet, as well as his prophecies, are 'at times directly and at other times, subtly entwined throughout these aspects'.

The dating of Isaiah 7 is a problematic challenge for many exegetes. Scholars such as Reventlow (2008:41), Sweeney (1996:55) and Williamson (2018:111) favour a late pre-exilic date, perhaps during the time of Josiah or shortly before. Reventlow (2008:41) also stated that some scholars still regard parts of Isaiah 7 as historical documentation. However, if it is not possible to link parts of this chapter to Isaiah himself, some scholars consider his disciples, or other contemporary witnesses, as the possible authors. But, it suffices to state that ' $[l]$ imitations of space, however, do not allow us to enter into that debate ... The identity of the author or authors, however, must remain an open question' (Reventlow 2008:41).

\section{Exposition of Isaiah 7:18-259}

This section consists of four short passages (7:18-19, 20, 21-22, 23-25) which all begin with the introductory phrase 'on that

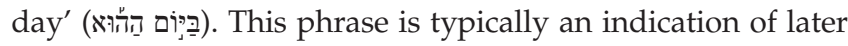
scribal activity and implies that these passages are a secondary composition on the part of the redactor. They were added to the two main passages (7:1-9.10-17), and expand as well as continue the warnings regarding the king of Assyria (7:17), who is announced as the vehicle by whom a day of judgement will come. These passages paint a dim future for Judah and this 'day' will be unprecedented in the terror it will bring: Assyria will humiliate its inhabitants, occupy the land and leave it ruined (Everson 2019:36-37; Kim 2016:62; Tull 2010:158).

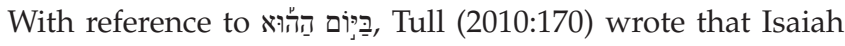
uses this phrase more than any other prophetic book. Here in Chapter 7, a series of disasters is highlighted with the

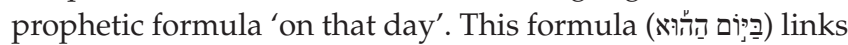
the verses 18, 20, 21 and 23 in a meaningful way to one

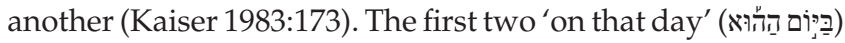
opening statements describe what $\mathrm{YHWH}$ will do to the people and the land of Judah, and the last two statements specify the impact of YHWH's actions on the people who are still living in Judah.

8.Williamson (2018:106) inferred: 'It follows, therefore, that in the combined versions of Isaiah $6+7$ that same principle in Ahaz's case is regarded as an illustrative primarily to "this people" as a whole'.

9.Cf. also Esterhuizen (2016:74ff.) with regard to this section.

\section{Verses 18-19}

Kaiser (1983:175) inferred that the prophetic formula connects these verses to the preceding section(s). Although we have this literary connection, this section's focus is not on King Ahaz anymore but has shifted towards the land and the

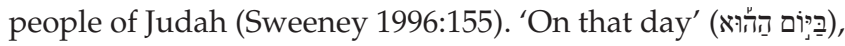
the cities and houses of Judah will be depopulated, and a catastrophe beyond any imagination will be brought upon the house of David. One can only imagine the terror and trauma this expectation of the catastrophe that will strike Judah, must have caused the inhabitants to experience. Kaiser (1983) furthermore described this metaphor being employed in these verses as follows:

In a deliberately mysterious but sufficiently evident metaphor, Yahweh is imagined as a bee-keeper who, with a whistle, lures a swarm of bees to his hives hidden in a cleft in the rock. (p. 175)

The goal of the series of metaphors is to emphasise the impact of the devastation, which will be caused by the superpower (cf. also Esterhuizen 2016:90; Prokhorov 2015:90). The sudden reference to Egypt in verse 18, and its connection to Assyria, is puzzling: 'the Lord will whistle for the fly that is at the end of the streams of Egypt and for the bee that is in the land of Assyria'. It is intriguing that this verse suddenly introduces Egypt, a nation which was not a threat to Judah, as Assyria was at that time in history. Although Assyria figures in Isaiah 1-39 as YHWH's instrument, Egypt does not. On the contrary, Egypt symbolises Judah's choices for wrong allegiances and false expectations. However, for Prokhorov (2015), it is possible that the:

[j]uxtaposition of these two superpowers in the text seeks to scorn Egypt by associating it with flies and equalling Assyria to a bee. The first insect is generally perceived as annoying while being neither useful nor very harmful for humans or animals, but the second one ranks much higher because it may both be of benefit (especially since honey is expected to become a staple food for both Immanuel and the people) and cause serious damage. The action of a sting is not dissimilar to that of an arrow, and the latter is explicitly associated in Isaiah 1-39 with both Assyria (37:33) and Yahweh the Chief-combatant (5:28). (pp. 90-91)

According to Smith (2007:217), it is evident in the unfolding story of the book of Isaiah that sometime in the future, foreign nations (cf. Is 5:25-30) would come into the land and here in verse 18 we read this infiltration is compared with YHWH's 'whistling' of flies and bees. This metaphor portrays a large swarm of enemy troops that will forcefully occupy the land and subsequently cause major trauma to the inhabitants. Verse 19 describes to the reader the location where the flies and the bees will settle, namely in the 'steep ravines, and in the clefts of the rocks and on all the thornbushes, and on all the pastures'. This metaphor describes the danger these foreign nations pose to Judah, as well as the fact that YHWH will command - whistle to them and they will come. For Smith (2007:217), these utterances are a symbolic metaphor to create an overwhelming and powerful picture of the millions of swarming insects that 
would make life intolerable for the inhabitants of the land. Judgment and despair are thus strong nuances inherent in these metaphors.

\section{Verse 20}

In the second subunit, the author compares God with a barber approaching with a razor, namely the king of Assyria (Everson 2019:37). The same threat of looming disaster, which we have in the first subunit, is here compared with the shaving of hair:

$[w]$ hich was equivalent to shaming by unmanning and castrating since beards were symbols of male power in the ancient Near East - an image of utter defeat and humiliation (2 Sam 10:1-5). (Kim 2016:62-63)

Verse 20 also expresses the disaster that will come from the Assyrians and the metaphor is telling of the shameful dishonour and harsh humiliation, which will be the fate of the inhabitants of Judah (Kaiser 1983:176).

The razor is a direct reference to the mighty Assyrian king and army who will be used by YHWH to shave the hair of the inhabitants of Judah. Judging from contemporary wall reliefs, one can see that men from Egypt were clean-shaven; Syrians and the men from Assyria had beards and Israelites were also bearded (Brettler \& Powell 2011:85). For Kaiser (1983:176), the significance of the metaphor surpasses the plain meaning. For him, the hair on the head and the pubic

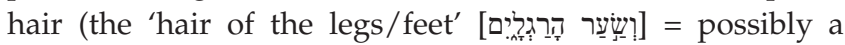
euphemism for the genital area) indicate all the hair on the body. This expression undoubtedly indicates the fact that Judah will be occupied by the enemy and subsequently will be depopulated and humiliated.

In the opinion of Smith (2007:118), the images used in this verse can be interpreted in two ways, namely either indicating the literal treatment of prisoners of war or indicating a metaphor for the shaving of the land. Both options are plausible in our perspective because both these nations who threatened Judah could have physically shaved the men's beards and hair in order to humiliate them and the metaphorical shaving of the land includes the trauma elements within this traumatic event. For Williamson (2018:188), the emphasis is here in this verse on the destruction of the land, with the additional element of the removal of much of the population. It could be that only a few people will survive this destruction, as we will come to see in the subsequent verses.

\section{Verses 21-22}

Different scholars have reflected on the question whether these two verses contain either an announcement of disaster or an announcement of salvation or both concurrently. In Roberts' (2015:127) interpretation, these two verses contain both threat and promise combined in this oracle. Tull (2010:171) remarked that the presence of 'milk' in verse 22 is an indication of abundance and verse 22 also echoes verse 15 in its reference to 'curds' and 'honey' ${ }^{10}$ Even though only a small number of people will survive the disaster, this is an indication of luxury.

Smith (2007:218), although, holds a different view, and in his interpretation, this oracle focuses only on the destruction of the land and thus cannot be read as a positive salvation oracle; although verse 22 speaks of plenty of food. According to him, this is reinforced by the reference in verse 21 of a man with only one cow and two sheep, which clearly makes a very small herd and makes survival impossible. Blenkinsopp (2000:236), on the other hand, thinks that one cow and two sheep represent the minimum for a household to survive and that the loss of cultivated land would have left ample land and space for grazing for the cattle still left in the land. According to Roberts (2015:127), these verses suggest that only a small remnant with a small number of animals will survive the crisis, but this small number of animals will suffice as they will produce ample to eat and to drink for the surviving remnant to have enough to eat.

In our interpretation, the threatening imagery in Isaiah 7:18-25 holds within the folds of the text remnants of hope and growth. Verses 21-22 tell of a future filled with hope. These verses speak of the survival of a remnant with enough 'milk' and 'curd to nourish them. Even within the fault lines of poverty, desolation and starvation, verse 21 uses the active verb 'alive' (היזָ) as a trace of hope within this traumatic situation. These verses underline hope and through survival and nourishment, growth and resilience can follow.

\section{Verses 23-25}

In this last subunit (vv. 23-25), the 'briers and thorns' echo verse 6 in the Parable of the Vineyard (Is 5:1-7). It is clearly meant to be understood as a continuation of the portrayal of a devastated countryside, which is characterised by its overgrown and ruined vineyard. This subunit is visibly marked by a three-fold 'there' (שָׁ) and the three-fold

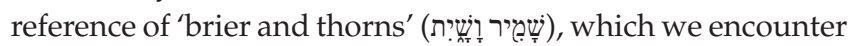
here in Isaiah 7 (Berges 2012:102; Kim 2016:63).

The last verses of this passage describe in vivid images a time of agricultural disaster. A picture of almost pandemic scopes is painted to portray the land devastation and socialcultural destruction. It is as if the land is suffering with its people. Roberts $(2015: 127)$ alluded that the landscape is described in two types of terrain, namely the countryside and the hill country after the Assyrian invasion. The imagery of the verses describes an overgrown landscape covered by brush and weed. Both Roberts (2015:127) and Williamson (2018:191) stated that this motif implies that the uncultivated land holds much danger as it will provide cover for wild animals and predators as the land becomes deserted of its inhabitants.

10.According to Kim (2016:63), it is an ironic twist that "the curds and honey, which could indicate abundant food (cf. v. 15), now connote "the produce of the uncultivated land," implying the impending hardship until God's deliverance' (cf. also Collins 2010:233-234). 
The specific reference to weaponry in the form of bows and arrows suggest, according to Williamson (2018:191), the danger of this overgrown and wild landscape. The fear of the looming danger is stressed with the three-fold references to

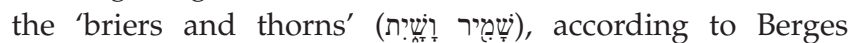
(2012:102). It is only in the cultivated hillsides that there will

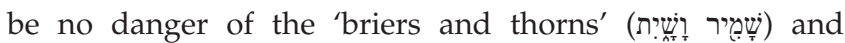
subsequently, the possible threat and fear of wild predators. Even though the hillside is usually portrayed as possible cultivated land, this textual description holds no abundance, but an array of misfortune for cattle, sheep and goats who will trample the land. The tenor of the conclusive line is clearly one of destruction, as the live-stock roam free over the once cultivated land. It is clear that the good news that was set to be delivered, has now been overturned and has become a message of despair and imminent trauma, as fear, anxiety and physical suffering is looming because of king Ahaz's and the people of Judah's lack of faith (Esterhuizen 2016:93).

\section{Conclusion}

In this article, the impact of the Covid-19 virus was used as a lens to read a text from the book of Isaiah. In a similar manner as the trauma of the looming and imminent land destruction holds a devastating threat to the people of Judah, the collective threat of the coronavirus causes trauma on societies and communities on different levels, namely on a psychological, physical and existential level. The immense psychological and existential damage of trauma caused by the terrifying and laming fear this virus has on the mental well-being of a society, asked for a theological reflection. We therefore regarded it as an imperative to engage with a biblical text that also describes the traumatic effects of an external threat on a society, namely to create a fearful and lame society.

In spite of the imminent threat and disaster, our text has shown a glimmer of hope. The atmosphere in verses 18-19 and 20 foretells the threat of invasion by the Assyrians where they will sweep over Judah like a plaque and total despair will follow. Verses 23-25 describe a devastated countryside as a result of the depopulation. However, the text also contains a sparkle of hope. Two verses, 'overgrown brush' on the one side and 'milk and honey' on the other side, are paradoxically placed against each other (vv. 22 and 23). Therefore, it emphasises on the one hand the hopeless situation of disaster but encircled with a small remnant of hope. Verses 21-22 hold the trace of hope as it depicts a small remnant that will remain and survive.

\section{Acknowledgements Competing interests}

The authors have declared that no competing interest exist.

\section{Authors' contribution}

All authors contributed equally to this work.

\section{Ethical considerations}

This article followed all ethical standards for a research without direct contact with human or animal subjects.

\section{Funding information}

This research received no specific grant from any funding agency in the public, commercial, or not-for-profit sectors.

\section{Data availability}

Data sharing is not applicable to this article as no new data were created or analysed during this study.

\section{Disclaimer}

The views and opinions expressed in this article are those of the authors and do not necessarily reflect the official policy or position of any affiliated agency of the authors.

\section{References}

Altmaier, E.M., 2019, Promoting positive processes after trauma, Academic Press, San Diego, CA.

Aster, S.Z., 2017, Reflections of empire in Isaiah 1-39. Responses to Assyrian ideology, Ancient Near East Monographs 19, SBL Press, Atlanta, GA.

Berges, U., 2012, The Book of Isaiah: Its composition and final form, Hebrew Bible Monographs 46, Sheffield Phoenix Press, Sheffield.

Blenkinsopp, J., 2000, Isaiah 1-39: A new translation with introduction and commentary, Anchor Bible 19, Doubleday, New York, NY.

Brettler, M.Z. \& Powell, M.A., 2011, 'Beards', in M.A. Powell (ed.), HarperCollins Bible Dictionary, p. 85, HarperOne, New York, NY.

Brueggemann, W., 1998, Isaiah 1-39, Westminster Bible Companion, Westminster John Knox, Louisville, KY.

Childs, B.S., 2001, Isaiah, OTL, Westminster John Knox, Louisville, KY.

Collins, J.J., 2010, 'The sign of Immanuel', in J. Day (ed.), Prophecy and prophets in ancient Israel. Proceedings of the Oxford Old Testament Seminar, LHB/OTS 531 pp. 225-244, T\&T Clark, New York, NY.

Erikson, K., 1995a, 'Notes on trauma and community', in C. Caruth (ed.), Trauma: Explorations in memory, pp. 183-199, John Hopkins University Press, Baltimore, MD.

Erikson, K., 1995b, A new species of trouble: The human experience of modern disaster, W. W. Norton \& Company, New York, NY.

Esterhuizen, E., 2016, 'A study of the tension between despair and hope in Isaiah 7 and 8 from a perspective of trauma and posttraumatic growth', unpublished DThthesis, UNISA, Pretoria, viewed 5 September 2020, from http://uir.unisa.ac.za/ thesis, UNISA, Pretoria,
handle/10500/22263.

Everson, A.J., 2019, The vision of the Prophets Isaiah. Hope in a war-weary world: A commentary, Wipf \& Stock, Eugene, OR.

Groenewald, A., 2018, “Trauma is suffering that remains": The contribution of trauma studies to prophetic studies', Acta Theologica 38(Suppl 26), 88-102. https://doi. org/10.18820/23099089/actat.Sup26.5

Herman, J., 1992, Trauma and recovery: The aftermath of violence - From domestic abuse to political terror, Basic Books, New York, NY.

Huremović, D., 2019, 'Brief history of pandemics (pandemics throughout history)', in D. Huremović (ed.), Psychiatry of pandemics: A mental health response to infection outbreak, pp. 7-36, Springer, Cham.

Joseph, A., 2020, 'At Harvard forum, three who know warn of "most daunting virus" in half a century', STAT, 07 March, viewed 5 September 2020, from https://www. statnews.com/2020/03/07/harvard-forumexperts-warn-most-daunting-virus-in50-years/.

Kaiser, O., 1983, Isaiah 1-12, OTL, SCM Press, London.

Kim, H.C.P.K., 2016, Reading Isaiah. A literary and theological commentary, Reading the Old Testament, Smyth \& Helwys, Macon, GA.

Luckhurst, R., 2008, The trauma question, Routledge, New York, NY

O'Donnell, K. \& Cross, K., 2020, Feminist trauma theologies: Body, scripture and church in critical perspective, SCM Press, London.

Prokhorov, A.V., 2015, The Isaianic Denkschrift and a socio-cultural crisis in Yehud. A rereading of Isaiah 6:1-9:6[7], FRLANT 261, Vandenhoeck \& Ruprecht, Göttingen.

Reventlow, H.G., 2008, 'A religious alternative to a political response to a severe political crisis: King Ahaz and the prophet Isaiah', in H.G. Reventlow \& Y. Hoffman (eds.), Religious responses to political crisis, LHB/OTS 444, pp. 36-51, T\&T Clark, New York, NY 
Roberts, J.J.M., 2015, First Isaiah: A commentary, Hermeneia, Fortress Press, Minneapolis.

Saul, J., 2014, Collective trauma, collective healing: Promoting community resilience in the aftermath of disaster, Routledge, New York, NY.

Smith, G.V., 2007, Isaiah 1-39: The new American commentary, Vol. 15a, B \& $\mathrm{H}$ Publishing Group, Nashville, TN.
Sweeney, M.A., 1996, Isaiah 1-39 with an introduction to prophetic literature, FOTL 16, Eerdmans, Grand Rapids, MI.

Tull, P.K., 2010, Isaiah 1-39, Smyth \& Helwys Bible Commentary, Smyth \& Helwys, Macon, GA.

Williamson, H.G.M., 2018, A critical and exegetical commentary on Isaiah 1-27. Volume 2: Commentary on Isaiah 6-12, ICC, Bloomsbury T\&T Clark, New York, NY. 